УДК 378.14

DOI 10.25205/1818-7919-2019-18-5-9-20

\title{
Информационная система
}

«Древнейшее искусство Сибири и Дальнего Востока»новый научно-образовательный ресурс в Новосибирском государственном университете

\author{
Л. В. Лбова ${ }^{1}$, В. В. Казаков ${ }^{1,2}$, К. Б. Жумадилов ${ }^{1}$ \\ ${ }^{1}$ Новосибирский государственный университет \\ Новосибирск, Россия \\ ${ }^{2}$ Новосибирский государственный университет экономики и управления \\ Новосибирск, Россия
}

\section{Аннотация}

Развитие электронных образовательных ресурсов в гуманитарной сфере университета является актуальной проблемой. В перспективе ее решение возможно с привлечением специалистов в области инфокоммуникационных технологий, заинтересованных преподавателей и студентов-археологов. В предлагаемой статье представлен новый электронный научно-образовательный ресурс, разработанный в НГУ и предназначенный для подготовки специалистов в области археологии Сибири и Дальнего Востока. Он выполнен как классическое веб-приложение с базой данных и интерфейсами просмотра и редактирования данных. Особенностью ресурса является наличие трехмерных моделей объектов, которые располагаются в интерфейсе просмотра. Дальнейшее развитие системы предусматривает пополнение банка экспонатов, применение методов компьютерного моделирования, сохранение модели в объеме с возможностью последующей репликации, что открывает новые перспективы в развитии трехмерной визуализации в исследовательской области и в образовании, в том числе в учебных программах по направлению подготовки «Археология».

Ключевые слова археология, высшее образование, информационная система, контент, 3D-модель

Благодарности

Исследование проведено при поддержке РНФ (проект № 18-78-10079)

Для ичтирования

Лбова Л. В., Казаков В. В., Жумадилов К. Б. Информационная система «Древнейшее искусство Сибири и Дальнего Востока» - новый научно-образовательный ресурс в Новосибирском государственном университете // Вестник НГУ. Серия: История, филология. 2019. Т. 18, № 5: Археология и этнография. С. 9-20. DOI 10.25205/1818-7919-2019-18-5-9-20

\section{Information System}

\section{"Prehistory Art of Siberia and the Far East":}

\section{A New Scientific and Educational Resource in Novosibirsk State University}

L. V. Lbova ${ }^{1}$, V. V. Kazakov ${ }^{1,2}$, K. B. Zhumadilov ${ }^{1}$

${ }^{1}$ Novosibirsk State University

Novosibirsk, Russian Federation

${ }^{2}$ Novosibirsk State University of Economics and Management

Novosibirsk, Russian Federation

Abstract

Purpose. Development of electronic educational resources in the humanitarian environment of higher school is an urgent problem of modern education. The aim of our work is to systematize didactic forms and approaches to the devel- 
opment of e-learning resources as exemplified by the interactive educational and methodological complex "Prehistoric Art of Siberia and the Far East".

Results. We describe models of electronic tutorials in terms of a modern direction, development of interactive teaching complexes. An original proprietary information system "Prehistoric Art of Siberia and the Far East" (mobileart.artemiris.org) contains information on the monuments of the Paleolithic age of Siberia, which is presented in a systematic way. Objects of the Siberian Paleolithic collections are attributed, provided with a scientific description, photographs, macro, three-dimensional models and a list of references.

Conclusion. Modern education at the university supposes a wide usage of information technology. Interactive educational and methodological complexes today can fully satisfy this need. 3D technology proposed for presenting archaeological materials not only provides effective illustrations of the context, but also implements a new, more sophisticated methodology for studying historical and cultural heritage. Enhanced capabilities of working with a virtual model of archaeological objects allow researchers and students to get more information remotely, which reduces the anthropogenic load on the object under study. The complex developed implies non-contact processing of museum exhibits with varying degrees of damage, using computer simulation techniques for the pre-excavation state of reconstruction, provides an opportunity to restore badly damaged or even gone objects and to preserve the model shape with a possibility of subsequent replication. All of the above forces us to open a new course in the educational programs for archaeology students. It is assumed that this educational segment will find its place in the new Federal State Educational Standard and will contribute to the formation of the competencies of a modern specialist.

Keywords

Archaeology, higher education, information system, content, 3D model

Acknowledgements

This work was supported by the Russian Science Foundation, project no. 18-78-10079

For citation

Lbova L. V., Kazakov V. V., Zhumadilov K. B. Information System "Prehistory Art of Siberia and the Far East": A New Scientific and Educational Resource in Novosibirsk State University. Vestnik NSU. Series: History and Philology, 2019, vol. 18, no. 5: Archaeology and Ethnography, p. 9-20. (in Russ.) DOI 10.25205/1818-7919-2019-18-59-20

\section{Введение}

В системе образования в высшей школе - основном источнике квалифицированных и конкурентоспособных кадров и базе фундаментальных и прикладных научных исследований, процессу создания и использования информационных технологий принадлежит особая роль. Особенностью системы высшего образования является то, что она выступает, с одной стороны, в качестве потребителя, пользователя, а с другой - создателя информационных технологий, которые впоследствии применяются в самых различных сферах. Развитие информационных технологий обусловило появление новой формы обучения - электронного образования (e-learning), т. е. обучения с использованием информационно-коммуникационных технологий. Основой электронного образования являются электронные образовательные ресурсы [Башмачников А. И., Башмачников И. А., 2003], представленные в электронно-цифровой форме (ГОСТ 52653-2006). В общем случае образовательный ресурс включает в себя структуру, предметное содержание и метаданные о них. Под последними понимается информация об образовательном контенте, характеризующая его структуру и содержание. Электронный образовательный ресурс может включать в себя информацию, сопроводительные данные, программное обеспечение и формы дидактического использования в процессе обучения. Структура, предметное содержание, методы и средства разработки и применения электронного образовательного ресурса определяются его функциональным назначением. Метаданные таких образовательных ресурсов содержат стандартизированную информацию, необходимую для поиска посредством технологической системы обучения. Контент электронного образовательного ресурса, прошедший редакционно-издательскую обработку, имеющий выходные сведения и предназначенный для распространения в неизменном виде, является электронным изданием (ГОСТ 7.60-2003).

Использование электронных средств обучения в учебном процессе в университете позволяет решить ряд дидактических задач: индивидуальное и дифференцированное обучение с учетом интересов студентов; расширение возможностей контроля с обратной связью и диаг- 
ностикой проблем понимания; осуществление самоподготовки, самоконтроля и самокоррекции; повышение эффективности обучения и усиление его мотивации [Хортон У., Хортон К., 2005].

В НГУ с 2015 г. практикуется реализации электронных образовательных ресурсов ${ }^{1}$. Развита площадка электронного тестирования и проверки знаний студентов ${ }^{2}$, предлагаются различные формы представления знаний в электронном формате.

Электронное учебное или учебно-методическое пособие, предназначенное для использования в образовательном процессе, должно пройти научное, литературное, дизайнерское и техническое редактирование, рецензирование и экспертизу для присвоения официального грифа, определяющего его вид и уровень использования.

Необходимо оговориться о том, что мы понимаем под термином «информационная система». Его официальное определение дано в ст. 2 Федерального закона от 27.07.2006 № 149Ф3 «Об информации, информационных технологиях и о защите информации». «Информационная система - это совокупность содержащейся в базах данных информации и обеспечивающих ее обработку информационных технологий и технических средств». Таким образом, под данным термином мы понимаем совокупность проверенных данных по источникам (археологическим и библиографическим) и технических средств, способных принимать, обрабатывать, хранить и представлять информацию пользователю в максимально короткие сроки [Горюнов, 2010]. Такие характеристики полностью соответствуют стандарту и целям образования в высшей школе. Предполагается, что этот образовательный сегмент и новые перспективы в развитии образовательных программ по направлению подготовки «Археология и этнография» найдут место в новых ФГОСах, практике образования в НГУ и других университетах и будут способствовать формированию компетенций современного специалиста.

\section{Материалы и обсуждение}

В НГУ электронные образовательные ресурсы для гуманитариев в целом и студентов, специализирующихся в области археологии и этнографии, представлены в ограниченном ассортименте (1 учебное пособие, 2 виртуальных музея, один из которых Музей истории НГУ, тестовые разработки по ряду дисциплин). Такая ситуация не может удовлетворять профессиональное сообщество, но решение проблемы находится вне компетенций и желаний отдельных преподавателей.

Контент электронного образовательного ресурса может быть представлен в различных видах.

Первый - это учебник, т. е. издание, содержащее систематическое изложение учебной дисциплины, ее разделов и частей, соответствующих учебной программе. Издание должно быть официально утверждено для использования в образовательном процессе соответствующего уровня образования.

Второй - учебное пособие, т. е. издание, частично или полностью дополняющее или заменяющее учебник и официально утвержденное для использования в образовательном процессе соответствующего уровня образования (например, учебное пособие «Первобытная культура» ${ }^{3}$ ). Ресурс используется в рамках дисциплин «Концептуальная антропология», «Первобытная культура и искусство», «Основы религиоведения», «Основы археологии» и др.

Третий - учебно-методическое пособие, т. е. издание, содержащее материалы по методике преподавания и изучения учебной дисциплины или ее раздела. Частично такие материалы размещаются на площадке el.nsu.ru в виде презентаций материалов лекций, списка рекомендованной литературы, электронных тестов.

\footnotetext{
${ }^{1}$ См., например: https://www.nsu.ru/n/education/online-education

${ }^{2}$ См.: https://el.nsu.ru

${ }^{3} \mathrm{http} / /$ ritual.vixpo.nsu.ru/?int=VIEW\&el=4\&templ=LECT_LIST
} 
Четвертый - учебное наглядное пособие, т. е. издание, как правило, содержащее изобразительные материалы, тексты лекций в помощь изучению и преподаванию. Такой проект был разработан более 20 лет назад в НГУ и представлен веб-ресурсом «Древнее искусство Сибири» ${ }^{4}$. Пособие состоит из разделов «Лекции» (авторы текстов - В. Д. Кубарев, В. И. Молодин, Н. В. Полосьмак, Л. М. Хаславская и др.), «Фонды» (коллекции изображений музейных предметов и краткие аннотации к ним), «Справочник» (библиография, словари, справочные материалы и т. п.). Ресурс подготовлен с участием ведущих сотрудников ИАЭТ СО РАН и НГУ, но, к сожалению, редко используется в практике преподавания и не имеет официального статуса.

Пятый - практикум, т. е. издание, содержащее практические задания и упражнения, способствующие усвоению пройденного материала (например, электронные тесты по предметам «Основы религиоведения», «Археология каменного века», «Методика организации НИР», расположенные на площадке el.nsu.ru). Тесты содержат не менее 300 заданий, распределенных по частям, соответствующим разделам дисциплины. Они активно используются в практике преподавания и проверки знаний по указанным дисциплинам.

В ряде проектов, реализуемых в рамках лаборатории междисциплинарного исследования первобытного искусства Евразии Гуманитарного института НГУ, сформированы несколько методических объектно-ориентированных блоков, различающихся уровнем детализации и предназначенных для различных целей образовательной и научной деятельности археологов. Например, развитие таких идей нашло отражение в создании 3D-галереи (3d.nsu.ru), где публикуются предметы археологических коллекций в форме трехмерных моделей и их информационный контекст (работа выполнялась в рамках гранта РГНФ 13-21-08002м и подготовки электронного образовательного ресурса «На пороге цивилизации...», Институт им. Пушкина). В ресурсе представлены функции просмотра и добавления моделей, описания предметов, расширенные возможности управления источниками освещения, выбора фона. Возможны и исследовательские приемы для пользователя: измерение расстояния между произвольными точками на предмете, включение (отключение) автопрокрутки и многое иное. Веб-приложение реализовано с помощью серверных скриптов, которые осуществляют работу с базой данных и генерацию пользовательских интерфейсов. При этом основная бизнеслогика приложения реализована на уровне браузера в HTML5 среде - вьюер трехмерной модели на основе WebGL, включающий инструменты навигации, освещение предмета и т. п.

Определенным ноу-хау проектного коллектива является разработанная методика создания 3D-моделей на основе фотограмметрии и сканирования как монументальных, площадных археологических объектов (петроглифы, поселения, пещеры), так и уникальных предметов древнейшего искусства Сибири. В основу разработки положен автоматизированный процесс документирования площадных объектов или артефактов в полевых (музейных) условиях; 3D-моделирование композиций наскальных изображений, отдельных петроглифов, археологических памятников - открытых стоянок, могильников, отдельных артефактов. Предложены способы обработки и трансформации моделей для различных целей исследования с ранжированием уровня доступа [Казаков, 2016; Леонов и др., 2014].

Создание информационной системы «Древнейшее искусство Сибири и Дальнего Востока», разработка концепции, подготовка материалов, проведение ряда исследований (например, трасологического, технологического), наполнение контента, оцифровка отдельных предметов в систематизированном виде были начаты в 2016 г. при работе с уникальными артефактами древнейшего искусства Сибири в Государственном историческом музее (Москва). Применялась стандартная методика фотограмметрии для работы с мелкими предметами (с использованием поворотного стола и частичной автоматизации процесса). Основы концепции данной информационной системы были заложены в 2012 г. [Лбова и др., 2013]. К на-

\footnotetext{
${ }^{4}$ http://museum.mmc.nsu.ru/?int=VIEW\&el=742\&templ=NEW_INTERFACE_PAGE
} 
стоящему времени система претерпела изменения при реализации на практике проекта как научного и образовательного ресурса.

В рамках проекта РНФ «Разработка технологий и информационной системы документирования и научного обмена археологическими данными» (сайт проекта: artemiris.org) информационная система «Древнейшее искусство Сибири и Дальнего Востока» ${ }^{5}$ занимает особое место. Она выполнена, как классическое веб-приложение с базой данных и интерфейсами просмотра и редактирования данных. Просмотр происходит по траектории «Начальная страница» - «Регионы» - «Регион» - «Памятник» - «Археологическая находка» (рис. 1; 2).

\section{Mobile Art Регионы 光}

Главная / Регионы / Кузнецкий Алатау

\section{Кузнецкий Алатау}

На территории известен единственный памятник верхнего палеолита с датированными культурными слоями в пределах ранней поры верхнего палеолита (28 - 36 тыс.л.н.) - Малая Сыя. Коллекция изделий персональной орнаментации довольно гомогенна, выполнена из «экзотического» сырья талькита и представлена готовыми артефактами, их заготовками и подготовленным к дальнейшей обработке сырьем Представлены предметы выраженной геометрической формы (круглые, ромбовидные, треугольные), уплощенные, орнаментированные как по краю, так и по поверхности Особый интерес представляют изделия фигурной формы из зеленоватого талькита, которая находит аналогии в европейских комплексах верхнего палеолита и ассоциируется с женскими образами.

В других палеолитических памятниках предгорьев Кузнецкого Алатау и Минусинской котловины также отмечены находки бусин, изделий геометрической формы из камня, но такие памятники, как Сабаниха, Ирба и др. относятся к более поздней эпохе палеолита (моложе 25 -20 тыс.л.н).

\section{Памятники}
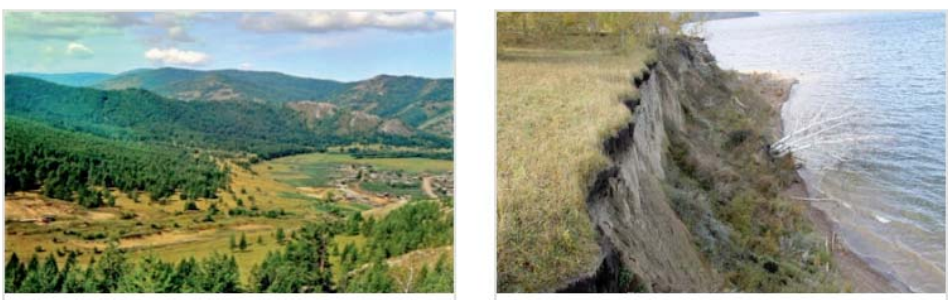

\section{Малая Сыя}

Разновременный геоархеологический объект (ранняя стадия верхнего палеолита)

\section{Сабаниха}

Археологический памятник классической стадии верхнего палеолита

\section{Публикации}

Лисицын Н.Ф. Поздний палеолит Чулымо-Енисейского междуречья. - СПб: Изд-во «Петербургское востоковедение», 2000. - С. 26-30

๑ Новосибирский государственный университет $\leftrightarrow$ Лаборатория ЛмипиЕ ГИ

Проект поддержан РНФ №18-78-10079

Puc. 1. Скриншот страницы региона Кузнецкого Алатау со списком археологических памятников Fig. 1. Screenshot of the Kuznetsk Alatau Region Page with a List of Archaeological Sites

\footnotetext{
${ }^{5} \mathrm{http}: / /$ mobileart.artemiris.org
} 
Главная / Регионы / Кузнецкий Алатау / Малая Сыя

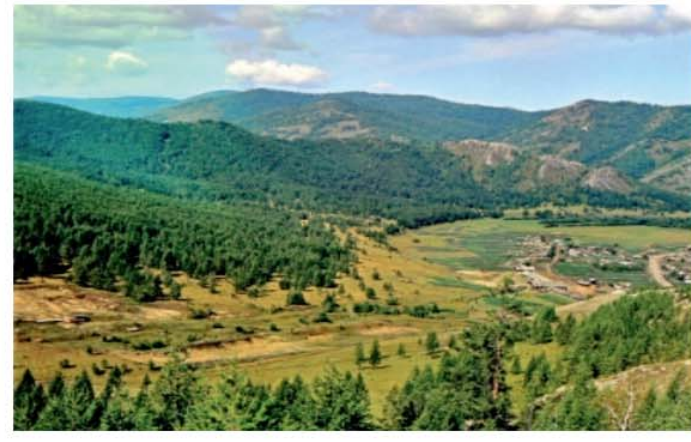

\section{Малая Сыя}

Верхнепалеолитическое местонахождение Малая Сыя расположено Южной Сибири, на стыке восточных предгорий Кузнецкого Алатау с территорией Минусинской котловины. Памятник относится к бассейну р. Чулым и приурочен к среднему течению р.Белый Июс. Местонахождение расположено на западном склоне лога, расчленяющего левый борт долины р. Белый Июс, на западной окраине села Малая Сыя. Первые археологические работы на памятнике проводились в 1974-1975 гг. открыто местонахождение Н.Д. Оводовым. Стационарно памятник исследовался Верхнечулымской экспедицией ИИФФ СО РАН в 19751981 гг., в 1992, и в 2000 гг. под руководством В.Е. Ларичева и Ю.П. Холюшкина

Каменная индустрия памятника имеет ярко выраженный верхнепалеолитический облик. Первичное расщепление направлено на получение пластинчатых заготовок, с изготовлением на них орудий

(концевые скребки, комбинированные орудия, остроконечники, выемчатые орудия, резцы). Распространены острия на отщепах, проколки, галечные орудия. Коплекция артефактов из кости и рога демонстрирует стандартный набор инвентаря для верхнепапеолитических памятников в который входят тесла, наконечники, шилья, лощила. Исследование украшений из талькита показало различные технологические принципы и культурные различия в их изготовлении

Радиоуглеродные даты аргументированно соотносят комплекс с каргинским временем с датировками в интервале 28 - 36 тыс. л.н.

\section{Коллекция}
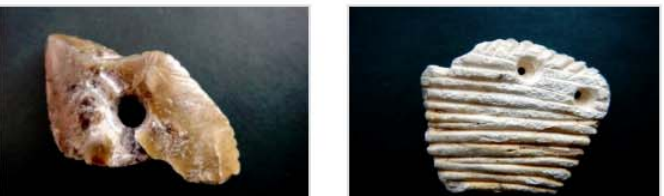

Фигурное изделие Фигурное изделие из зеленоватого талькита с центральным отверстием

Трапециевидное изделие Орнаментированное изделие подтрапециевидной формы с отверстиями

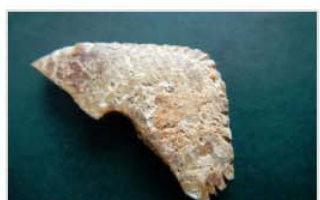

Изделие треугольной формы

Изделие треугольной формы из рыжеватого талькита с насечками

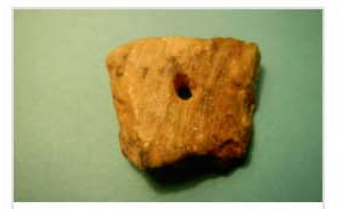

Заготовка для бусины

Заготовка трапециевидной формь

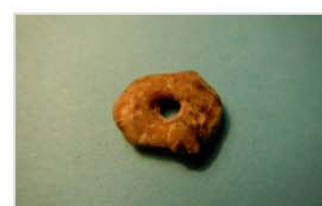

\section{Бусина}

Бусина округлая, крупная

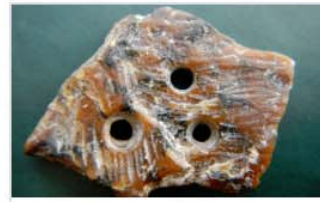

Ромбовидное изделие с тремя отверстиями Изделие из коричневого талькита с тремя отверстиями

\section{Публикации}

Ларичев В. Е., Холюшкин Ю. П. Археология врехнепалеолитического поселения Малая Сыя // Археология, геология и палеография палеолитических памятников Юга Средней Сибири (Северо-Минусинская впадина, Кузнецкий Алатау. Восточный Саян). Красноярск. изд-во Зодиак, 1992. - С. 109-122. Лбова Л.В., Панов В.С., Зенин В.Н., Барков А.В. Новые данные о радиоуглеродном возрасте памятника Малая Сыя. // Проблемы археологии, этнографии, антропологии Сибири и сопредельных территорий. Мат-лы Итоговой сессии Института археологии и этнографии СО РАН 2015 года. - Т XXI - НовосИбирСК: ИзД-Во ИАЭТ СО РАН, 2015 С. 103-106.

Лбова Л. В., Волков П. В., Долгорукова Н. А., Барков А. В., Ларичев В. Е. Предметы неутилитарного назначения местонахождения Малая Сыя (технологический аспект) // Вестник НГУ. Серия: История, филология. 2014. Т. 13. Вып. 5: Археология и этнография. - С. 91-100.

лбова Л. В., Кулик Н. А., Волков П. В., Барков А. В., Ванхарен М., Марченко Д. В., Ковалев В.С. Технология обработки «экзотических» минеральных ресурсов в позднем палеолите Южной Сибири (по материалам местонахождения Малая Сыя) // Stratum plus, 2018, №1, с. 199-214. Лисицын Н.Ф. Поздний палеолит Чулымо-Енисейского междуречья. - СПб: изд-во Центр «Петербургское востоковедение», 2000 - С. 26-30 Холюшкин Ю. П. Поселение Малая Сыя - ранний этап верхнего палеолита Сибири (к проблеме начала становления культур Ноmo sapiens в Северной Азии) // Астроархеология - естественнонаучный инструмент познания протонаук и астральных религий жречества древних культур Хакасии Красноярск: изд-во Город, 2009. - С. $137-145$

\section{(0 Новосибирский государственный университет $\mapsto$ Лаборатория ЛМИПИЕ ГИ} Проект поддержан РНФ №18-78-10079

Puc. 2. Скриншот страницы памятника Малая Сыя со списком археологических находок Fig. 2. Screenshot of the Malaya Syya Site Page with a List of Archaeological Finds 
В системе представлены памятники начального и раннего верхнего палеолита Сибири, различные формы искусства каменного века. Это мозаичное сочетание технологий расщепления камня, обработки кости и рога, а также удивительное разнообразие ископаемых антропологических материалов, представляющих различные виды и подвиды рода Ното. Каждый объект атрибутирован и представлен полями «аннотация», «описание», «техника изготовления», «следы утилизации», «место хранения», «инвентарный номер», «музейная КАМИС», «размеры», «материал», «датировка», «культура», «автор раскопок», «год раскопок», «публикации», «фотография», «материалы макрофотосъемки». Отдельным элементом является 3D-модель, которая подгружается из 3D-галереи НГУ ${ }^{6}$ (рис. $\left.3 ; 4\right)$. Для регионов, памятников и предметов коллекции представлены развернутые научные описания, включая список литературы. Регионы отмечены на карте, что дает представление об их взаимном расположении в пространстве.

\section{Категория «Археология»}
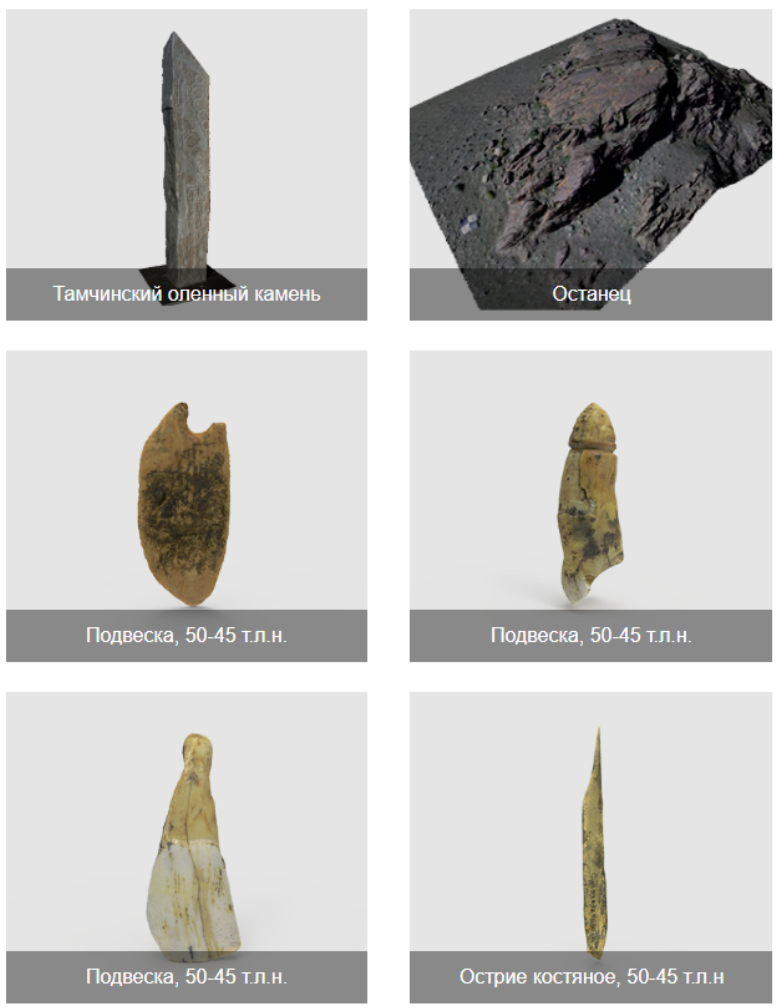

\section{Категории}

Археология

Разное

Археология

неразобранное

Снаряжение коня

Микролиты

Мальта

Студенческая практика НГУ

Петроглифы

Puc. 3. Скриншот страницы 3D галереи, категория «Археология»

Fig. 3. Screenshot of 3D Gallery Page, Category "Archaeology"

\footnotetext{
${ }^{6}$ См.: 3d.nsu.ru
} 


\section{Malta Скульптура Предметы престижа Бижутерия 炎}

Главная / Скульптура / Орнитоморфная скульптура / Кормящийся лебедь

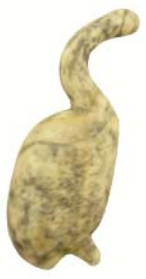

\section{Кормящийся лебедь}

Изображение водоплавающей птицы. Изделие имеет подовальную форму тела и изогнутую шею. Крылья не обозначены рельефом. В хвостовой части имеется овальное двухстороннее отверстие.

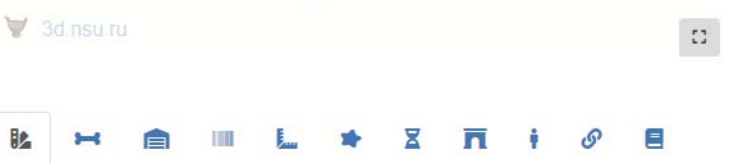

\section{Техника изготовления}

Вероятно, при формировании шеи, туловища и ножек использовался резец и строгальный нож. Следы формообразования перекрыты следами от контакта с мелкозернистым абразивом. Шлифовка однородная, под шлифорвкой найдены дендриты. Отверстие выполнено, вероятно, с использованием развёртки.
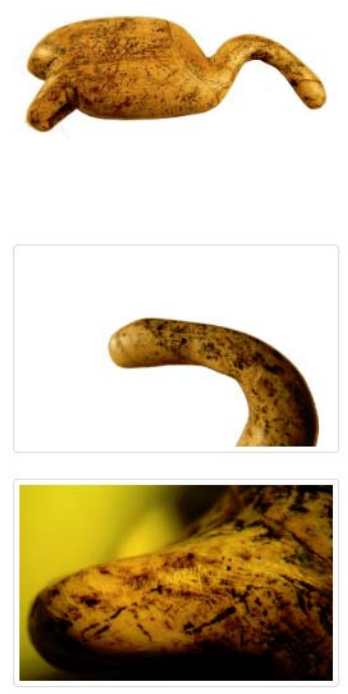
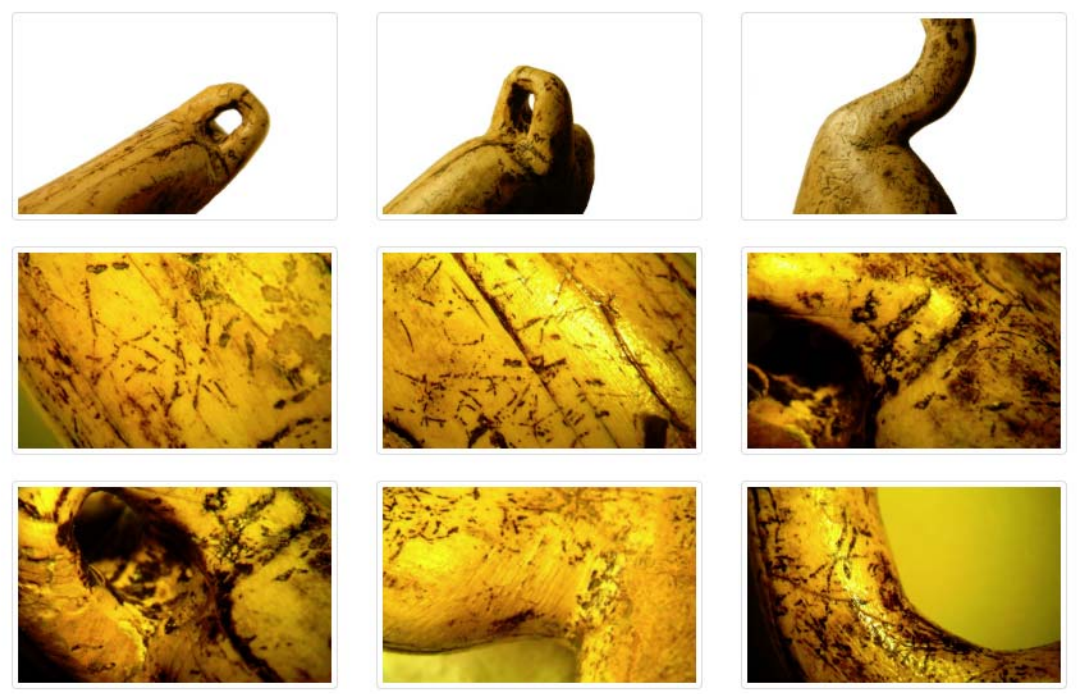

() Новосибирский государственный университет ↔ Лаборатория ЛмиПИЕ ГИ

Проект поддержан РНФ № 18-78-10079, РФФИ - CNRS № 17-056-16-16

Puc. 4. Скриншот страницы с трехмерной моделью Fig. 4. Screenshot of Page with a Three-Dimensional Model

На данный момент коллекция предметов мобильного искусства в информационной системе насчитывает около 50 экспонатов, при этом контент активно наполняется, в том числе привлекаются студенты, занимающиеся исследованием таких материалов. В дальнейшем предполагается развитие контента с привлечением и более поздних материалов - эпох мезолита и неолита.

Интерфейс редактирования доступен узкому кругу пользователей - авторам контента и применяется для пополнения коллекций предметов, памятников и регионов, а также редак- 
тирования сведений по уже введенным объектам. Ввод данных осуществляется по специальным полям формы, отдельно на русском и английском языках. Поля обязательны к заполнению на обоих языках.

Уникальной особенностью ресурса является наличие трехмерных моделей объектов коллекций. Они располагаются в интерфейсе просмотра, быстро загружаются и могут управляться непосредственно с веб-страницы. Загрузка моделей происходит через ресурс «3D галерея Новосибирского государственного университета» (см. рис. 3). В процессе загрузки в базу данных трехмерные модели преобразуются в один из наиболее сжимаемых 3D-форматов - Draco от Google Open Source сообщества. Трехмерные модели в таком формате легко загружаются в веб-браузерах современных компьютеров и мобильных устройств по стандартным каналам связи, в том числе 3G. При этом трехмерные модели несут в себе большее количество информации, чем обычные фотографические снимки. Во-первых, в формате 3D объект представлен со всех сторон, в отличие от плоского изображения. Во-вторых, на трехмерной модели предмета сохранен рельеф поверхности. В-третьих, с помощью специальных инструментов возможно измерение геометрических параметров предмета, включая глубину и форму рельефа (см. рис. 4).

Трехмерные модели 3D галереи НГУ также используются на информационной панели площадки музея НГУ. На экране отображается трехмерная модель объекта, его название и краткое описание, по умолчанию трехмерный объект находится в режиме автоматического вращения, но также допускается возможность управления положения объекта с помощью компьютерной мыши или других устройств ввода.

Таким образом, впервые тематически систематизированные и наглядно представленные предметы палеолитических коллекций способствуют целостному восприятию у обучающихся исторического материала с точки зрения развития технологий обработки материалов, использования предметов, их значения для реконструкции различных сторон исторического прошлого. Сопровождающие фотоматериалы в высоком разрешении позволяют изучать предметы со значительной степенью детализации, включая орнаментацию, следы утилизации и технологии изготовления. Контент, представленный одновременно на двух языках русском и английском, в рамках данной информационной системы может быть использован для преподавания гуманитарных дисциплин (археологии) в иностранных вузах и в российских вузах для иностранных студентов.

Разработка и наполнение предлагаемой информационной системы связана с рядом проблем научного характера, а также с необходимостью организации адекватного представления знаний. В настоящее время в связи с ростом в геометрической прогрессии объема новых материалов и научной документации встает вопрос об оптимизации способов хранения и обработки такой информации. Известны несколько десятков файловых серверов, позволяющих хранить и публиковать подобные объемы данных. Например, для публикации архивов археологических материалов широко используется информационная система Archaeology Data Service ${ }^{7}$ (далее ADS). Цель ADS - собирать, описывать, каталогизировать, сохранять и предоставлять пользователям поддержку цифровых ресурсов, которые создаются как продукт археологических исследований. ADS также несет ответственность за продвижение стандартов и руководств по созданию, описанию, сохранению и использованию археологической информации. Обучение студентов-археологов в НГУ в рамках спецкурса в работе с подобного рода ресурсами может быть организовано как целевым способом, так и дисперсным, что потребует привлечения заинтересованных преподавателей.

\section{Заключение}

Современное образование в высшем учебном заведении предполагает широкое использование возможностей новых информационно-коммуникационных технологий. Интерактивный

\footnotetext{
${ }^{7} \mathrm{http}: / /$ archaeologydataservice.ac.u
} 
учебно-методический комплекс позволяет активизировать творческую составляющую образования, отойти от сложившихся стереотипов подачи материала в высшей школе, совершенствовать методическое и информационное обеспечение образовательной среды, способствует развитию образовательных технологий, самостоятельной практической подготовки и проверки знаний, активизирует научно-исследовательскую работу студента (см., например: [Гущина, 2011; Косичкина, 2016] и др.).

Преимущества 3D-технологии в археологическом исследовании выражены не только как способ иллюстрации [Doneus, Neubauer, 2005; Forte, 2014]. Полученная трехмерная цифровая копия объекта предоставляет пользователям возможность работы с виртуальными копиями в любых проекциях, что требует совершенствования не только программ заданного уровня доступа, но и степени образовательной компетенции. Дистанционный способ исследования археологического объекта, в свою очередь, значительно ослабляет проблему сохранности (разрушения) исторических (археологических) объектов и предполагает дальнейшее развитие таких методик [Frischer, Dakouri-Hild, 2008; Barcelo et al., 2003; Forte, 2010] как в научнообразовательной, так и в рекреационной среде. Бесконтактная обработка музейных экспонатов с повреждениями, применение методов компьютерного моделирования для восстановления объекта до раскопок, реставрации разрушающихся объектов, сохранение модели в объеме с возможностью последующей репликации открывают новые перспективы в развитии трехмерной визуализации в исследовательской области, создают возможности для реставрации и консервации уникальных объектов, обеспечивают творческие перспективы образовательных программ по направлению подготовки «Археология». Предполагается, что этот образовательный сегмент найдет место в новых Федеральных государственных образовательных стандартах, обеспечивая формирование компетенций современного специалиста.

\section{Список литературы}

Башмачников А. И., Башмачников И. А. Разработка компьютерных учебников и обучающих систем. М.: Филинъ, 2003. 616 с.

Горюнов В. С. Информационные системы в образовании // Молодой ученый. 2010. Т. 2, № 5. C. $159-161$.

Гущина Л. А. Интерактивный учебно-методический комплекс как средство формирования учебной среды // Педагогика: традиции и инновации: Материалы Междунар. науч. конф. Челябинск: Два комсомольца, 2011. Т. 2. С. 66-67.

Казаков В. В. Применение информационных технологий в задачах Лаборатории мультидисциплинарных исследований первобытного искусства Евразии НГУ // Вестник НГУ. Серия: Информационные технологии. 2016. Т. 14, № 4. С. 50-57.

Косичкина А. С. Особенности проектирования и разработки электронных образовательных ресурсов для образовательной организации // Молодой ученый. 2016. № 27. С. 23-27.

Леонов А. В., Аникушкин М. Н., Бобков А. Е., Рысь И. В., Козликин М. Б., Шуныков М. В., Деревянко А. П., Батурин Ю. М. Создание виртуальной 3D-модели Денисовой пещеры // Археология, этнография и антропология Евразии. 2014. № 3 (59). С. 14-20.

Лбова Л. В., Панина Н. Л., Казаков В. В., Бочарова Е. Н., Арзамасова А. А. Виртуальная музеефикация объектов ранних периодов становления и развития искусства в информационной системе «Первобытная культура и искусство Северной Азии» (концепция нового образовательного ресурса) // Вестник НГУ. Серия: История, филология. 2013. Т. 12, № 7: Археология и этнография. С. 6-14.

Хортон У., Хортон К. Электронное обучение: инструменты и технологии. М.: ИД КУДИЦОБРАЗ, 2005. $640 \mathrm{c}$.

Barcelo J. A. De Castro, O., Travet D., Vicente, O. A. 3D model of an archaeological excavation. The Digital Heritage of Archaeology. Computer Applications and Quantitative methods in Archaeology, 2003, no. 33, p. 85-87. 
Doneus, M. Neubauer W. Laser scanners for 3D documentation of stratigraphic excavations. In: Baltsavias et al. (eds.). Recording, Modeling and Visualization of Cultural Heritage. Taylor \& Francis, 2005, p. 193-203.

Forte M. Introduction to Cyber Archaeology. In: Forte M. (ed.). Cyber Archaeology. BAR International Series, 2177. Oxford, 2010, p. 9-13.

Forte M. 3D Archaeology. New Perspectives and Challenges. The example Chatalhoyuk. Journal Eastern Mediterranean Archaeology, 2014, vol. 2, no. 1, p. 1-29.

Frischer B., Dakouri-Hild A. Beyond illustration: $2 \mathrm{~d}$ and $3 \mathrm{~d}$ digital technologies as tools for discovery in archaeology. Oxford, Archaeopress, 2008, 363 p.

\section{References}

Barcelo J. A. De Castro, O., Travet D., Vicente, O. A. 3D model of an archaeological excavation. The Digital Heritage of Archaeology. Computer Applications and Quantitative methods in Archaeology, 2003, no. 33, p. 85-87.

Bashmachnikov A. I., Bashmachnikov I. A. Razrabotka komp'yuternykh uchebnikov i obuchayushchih sistem [Development of Computer Textbooks and Training Systems]. Moscow, Filin Publ., 2003, 616 p. (in Russ.)

Doneus, M. Neubauer W. Laser scanners for 3D documentation of stratigraphic excavations. In: Baltsavias et al. (eds.). Recording, Modeling and Visualization of Cultural Heritage. Taylor \& Francis, 2005, p. 193-203.

Forte M. 3D Archaeology. New Perspectives and Challenges. The example Chatalhoyuk. Journal Eastern Mediterranean Archaeology, 2014, vol. 2, no. 1, p. 1-29.

Forte M. Introduction to Cyber Archaeology. In: Forte M. (ed.). Cyber Archaeology. BAR International Series, 2177. Oxford, 2010, p. 9-13.

Frischer B., Dakouri-Hild A. Beyond illustration: $2 \mathrm{~d}$ and $3 \mathrm{~d}$ digital technologies as tools for discovery in archaeology. Oxford, Archaeopress, 2008, 363 p.

Goryunov V. S. Informatsionnye sistemy v obrazovanii [Information Systems in Education]. Molodoi uchenyi [Young Scientist], 2010, vol. 2, no. 5, p. 159-161. (in Russ.) URL: https:// moluch.ru/archive/16/1540/ (accessed 13.03.2019)

Gushchina L. A. Interaktivnyi uchebno-metodicheskii kompleks kak sredstvo formirovaniya uchebnoi sredy [Interactive Educational and Methodological Complex as a Means of Forming Educational Environment]. In: Pedagogika: traditsii i innovatsii: materialy Mezhdunarodnoi nauchnoi konferentsii [Pedagogy: traditions and innovations]. Materials of the Intern. scientific conf. Chelyabinsk, Dva komsomol'tsa Publ., 2011, vol. 2, p. 66-67. (in Russ.) URL: https://moluch.ru/conf/ped/archive/19/1028/ (accessed 13.03.2019) (in Russ.)

Horton U., Horton K. Elektronnoe obuchenie: instrumenty i tekhnologii [E-learning: Tools and Technologies]. Moscow, ID KUDITS-OBRAZ Publ., 2005, 640 p. (in Russ.)

Kazakov V. V. Primenenie informacionnykh tekhnologii $v$ zadachakh Laboratorii mul'tidistsiplinarnykh issledovanii pervobytnogo iskusstva Evrazii NGU [The Use of Information Technology in the Tasks of the Laboratory of Multidisciplinary Studies of the Primitive Art of Eurasia at Novosibirsk State University]. Vestnik NSU. Series: Information Technology, 2016, vol. 14 , no. 4 , p. $50-57$. (in Russ.)

Kosichkina A. S. Osobennosti proektirovaniya i razrabotki elektronnykh obrazovatel'nykh resursov dlya obrazovatel'noi organizatsii [Design and Development Features of Electronic Educational Resources for Educational Organizations]. Molodoi uchenyi [Young scientist], 2016, no. 27, p. 23-27. (in Russ.) URL: https://moluch.ru/archive/131/36593/ (accessed 13.03.2019)

Lbova L. V., Panina N. L., Kazakov V. V., Bocharova E. N., Arzamasova A. A. Virtual'naya muzeefikatsiya ob' ektov rannikh periodov stanovleniya i razvitiya iskusstva $\mathrm{v}$ informatsionnoi sisteme «Pervobytnaya kul'tura i iskusstvo Severnoi Azii» (konceptsiya novogo obrazovatel'nogo resursa) [Virtual Museefication of Objects of the Early Periods of the Formation and Development of Art in the Information System "Primitive Culture and Art of 
Northern Asia" (a concept of a new educational resource)]. Vestnik NSU. Series: History and Philology, 2013, vol. 12, no. 7: Archaeology and Ethnography, p. 6-14. (in Russ.)

Leonov A. V., Anikushkin M. N., Bobkov A. E., Rys I. V., Kozlikin M. B., Shunkov M. V., Derevianko A. P., Baturin Yu. M. Sozdanie virtual'noi 3D-modeli Denisovoi peshchery [Creating a Virtual 3D-Model of the Denisova Cave]. Archaeology, Ethnography and Anthropology of Eurasia, 2014, no. 3 (59), p. 14-20. (in Russ.)

Материал поступил в редколлегию

Received

15.01.2019

\section{Сведения об авторах}

Лбова Людмила Валентиновна, доктор исторических наук, профессор; профессор кафедры археологии и этнографии Гуманитарного института Новосибирского государственного университета (ул. Пирогова, 1, Новосибирск, 630090, Россия)

lbovapnr5@gmail.com

ORCID 0000-0003-4103-7785

Казаков Владислав Витальевич, кандидат технических наук, старший научный сотрудник Лаборатории мультидисциплинарных исследований первобытного искусства Евразии Новосибирского государственного университета (ул. Пирогова, 1, Новосибирск, 630090, Россия), доцент Новосибирского государственного университета экономики и управления (ул. Каменская, 56, Новосибирск, 630099, Россия)

vkazakov@phys.nsu.ru

ORCID 0000-0001-8127-9602

Жумадилов Каир Бекбатырович, аспирант механико-математического факультета Новосибирского государственного университета (ул. Пирогова, 1, Новосибирск, 630090, Россия)

zhumadilov@nsu.ru

ORCID 0000-0002-8355-5241

\section{Information about Authors}

Liudmila V. Lbova, Doctor of Historical Sciences, Full Professor; Professor of the Department of Archaeology and Ethnography of the Humanitarian Institute at the Novosibirsk State University (1 Pirogov Str., 630090, Novosibirsk, Russian Federation)

lbovapnr5@gmail.com

ORCID 0000-0003-4103-7785

Vladislav V. Kazakov, Candidate of Engineering Sciences, senior researcher at the Laboratory of Multidisciplinary Research on Prehistoric Art in Eurasia at the Novosibirsk State University (1 Pirogov Str., 630090, Novosibirsk, Russian Federation); Associate Professor at Novosibirsk State University of Economics and Management (56 Kamenskaya Str., Novosibirsk, 630099, Russian Federation) vkazakov@phys.nsu.ru ORCID 0000-0001-8127-9602

Kair B. Zhumadilov, Postgraduate Student at the Faculty of Mechanics and Mathematics at the Novosibirsk State University (1 Pirogov Str., 630090, Novosibirsk, Russian Federation) zhumadilov@nsu.ru ORCID 0000-0002-8355-5241 